\title{
Organizational Justice, Job Satisfaction and Organizational Citizenship Behavior in Higher Education Institutions: A Research Proposition in Vietnam*
}

\author{
Le Nguyen Thanh Dong ${ }^{1}$, Nguyen Ngoc Duy Phuong ${ }^{2}$
}

Received: May 30, 2018 Revised: July 20, 2018 Accepted: July 30, 2018

\begin{abstract}
Higher Education Institutions (HEIs) are place contributing to the intellectual advancement of the nation, quality human resource, and to a number of socio-economic improvements for society and organizations. Despite facilitators and staffs are the bare-bone of HEls, there is a scarcity of research, both conceptual and empirical, focusing on their organizational citizenship behaviors (OCB). To attempt to fill this gap, this article develops a conceptual model of OCB under influencing of organizational justice and job satisfaction. The prospective respondents were chosen randomly from HEls (public and private). Individuals have been employed at least one year and above will be the unit of analysis in which the experimental test of the proposed model will be conducted. The results suggest that organizational citizenship behavior is one of the most important factor influence the organizational performance. Furthermore, the performance of HEls does not affect only the national human resources, but also impact on national economy. In this context, a conceptual framework is proposed to study the determinants of organizational citizenship behavior in the form of organizational justice and job satisfaction. Additionally, the ultimate benefits of OCB through perceived organizational justice with job satisfaction as mediator is enlightened. Finally, the authors discuss the managerial implications of their research.
\end{abstract}

Keywords: Organizational Justice, Job Satisfaction, Organizational Citizenship Behaviors, Higher Education Institution, Vietnam.

JEL Classification Code: M10, M12, M54.

\section{Introduction}

Human resource (HR) is one of the most valuable properties for organizations. Not like other resources, HR

* The paper was presented initially at 2018 International Conference on Business and Economics (ICBE2018) and the 14th International Conference of KODISA that was held in Seoul, South Korea, June 25-27, 2018. This paper is a substantially revised and expanded version of the paper presented at ICBE2018 conference. The authors have taken into account all the comments of Editors, Session Chairs and Reviewers in the revised manuscript. The authors greatly appreciate Editors, Session Chairs and Reviewers for their valuable comments, interest in and support of this research.

1 First Author, PhD student, International University, Vietnam National University, Ho Chi Minh City, Vietnam.

Email: donglnt@uef.edu.vn

2 Corresponding Author, Professor, International University, Vietnam National University, Ho Chi Minh City, Vietnam [Postal Address: Quarter 6, Liinh Trung Ward, Thu Duc District, Ho Chi Minh City, 700000, Vietnam] Email: phuongnida@gmail.com really is the core source of any organizations. Many organizations have been using $H R$ as their core competencies. In any organization, the superior goal is improving its performance, particular, in HEIs, the quality of $\mathrm{HR}$ is the most influence factor affects the performance or quality of students. It is affected by organizational policies and culture. Human resources are the main key effect on organizational performance (Becker \& Gerhart, 1996). Education systems, in particular higher education systems, not only hold an important role in education systems, but also in economy of every country. Higher Education Institutions (HEIs) are place contributing to the intellectual advancement of the nation, quality human resource, and to a number of socio-economic improvements for society and organizations. Quality of graduated students could be considered as the most important performance indicator of HEls.

The World Bank and United Nations Educational, Scientific and Cultural Organization (UNESCO) jointly commissioned a study on the future of higher education in developing countries. The findings suggested that faculty 
members in developing countries were less motivated, rewarded poorly and under qualified in comparison to academic staff in developed economies. Academics of developing countries are faced with these critical issues and ultimately this leads to less commitment and as a result an increase in the intention to leave. Lee (2004) confirmed these findings and suggested that teachers are offered fewer financial incentives, leading to an absence of commitment and higher turnover.

Organ (1988) suggested that organizations should consider role of organizational citizenship behavior (OCB) as important factor for increasing the spontaneous, innovative and cooperative attitudes in a way to respond to the constantly changing demands aiming to promote efficiency. Organ showed that job satisfaction is predictor of the "good citizen". He also indicated that workers perceive job satisfaction in terms of highly individualized, instinctive evaluations of fairness in their workplace. Chelagat, Chepkwony, and Kemboi (2015) agreed that OCB have a positive and significant effect on employee performance. Furthermore, Turnipseed and Rassuli (2005) found that manager's benefit from positive OCB as well as employees.

\section{Conceptual Framework and Hypotheses Development}

This study will propose a comprehensive model that encompasses how organization justice factors affect employee's job satisfaction and organizational citizenship behavior. Based on the conceptual model and literature review, seven hypotheses have been articulated to describe the impact of organizational justice on employee's job satisfaction and organizational citizenship behavior.

\subsection{Organizational Citizenship Behavior}

Batman and Organ (1983) were first introduced the term organizational citizenship behavior (OCB) to science world. OCB has been thought as personal and arbitrary behaviors which were not correctly defined by the formal remuneration system of organization and generally increased organization's performance. Arbitrary means that this behavior is not among the occupational duties or role behaviors and it is not among the employees' recruitment commitment and it is not compulsory for employees to do it (Podsakoff, Mackenzie, Paine, \& Bachrach, 2000). Since OCB presented, many research studies have conducted with the five-factor conceptualization suggested by Organ (1988). These factors are: altruism (helping specific others); civic virtue (keeping up with important matters within the organization); conscientiousness (compliance with norms); courtesy (consulting others before taking action); and sportsmanship (not complaining about trivial matters). Although a great deal has suggested to be condensed in few studies (MacKenzie, Podsakoff, \& Fetter, 1991) and be supported for a three-factor model of OCB: "conscientiousness" is removed, and "altruism" and "courtesy" are combined to form a single "helping" dimension (Podsakoff \& MacKenzie, 1994), the original five dimensions of OCB still the objectives for researching of behavior scientists.

The majority of the research studies conducted and concluded that OCB as behaviors that have positive impact on the organizations productivity and effectiveness (Turnipseed \& Rassuli, 2005; Koster \& Sanders, 2006). Hence, it is necessary to have a research on OCB and factors influence it, and, the present study concentrates on OCB as consequences of organizational justice (Yadav, 2016).

\subsection{Organization Justice}

Organizational justice is the employees' perception of the fairness with which they have been treated by an organization (Greenberg \& Colquitt, 2006). Organizational justice can be interpreted as a virtue allowing for mutual consideration and involving both relationships with others and outcomes that affect others' physical, psychological and social welfare (Cropanzano, Rupp, Mohler, \& Schminke, 2001). The components of organizational justice have often been divided into three aspects: distributive justice, procedural justice and interactional justice (Leventhal, 1980; Bies \& Moag, 1986; Masterson, Lewis, Goldman, \& Taylor, 2000; Cropanzano Rupp, Mohler, \& Schminke, 2001; Iqbal, 2013). Leventhal (1980) established some core attributes that make procedures justice. A justice process is one that is applied consistently to all, free of bias, accurate, representative of relevant stakeholders, correctable and consistent with ethical norms. Cropanzano (2007) agrees with core attributes that make procedures justice suggested by Leventhal (1976), procedural justice refers to the means by which outcomes are allocated, but not specifically to the outcomes themselves.

Bies and Moag (1986) introduced the idea of interactional justice. Originally, interactional justice identified on the basic of a study of expectations for interpersonal treatment during recruitment. These included justification (explaining the basis for decisions), truthfulness (an authority figure being candid and not engaging in deception), authority (being polite rather than rude), and propriety (refraining from improper remarks or prejudicial statements (Colquitt, 2001). Awang and Ahmad (2015), on their study of impact of 
organizational justice on OCB found that distributive justice and interactional justice are significant in impact on OCB with the index .19 and .25 , consecutively.

\subsection{Relationships between Organization Justice and Employee's Job Satisfaction}

Job satisfaction can be generally defined as an employee's attitude towards his/her job or how people feel about their jobs and different aspects of their jobs (Brief, 1998; Spector, 1997) and the extent to which employees like their work (Ellickson \& Logsdon, 2002). Colquitt, Conlon, Wesson, Porter, and $\mathrm{Ng}$ (2001) reported that distributive justice was an important predictor of job satisfaction. Furthermore, Masterson, Lewis, Goldman and Taylor (2000) found procedural justice to be a stronger predictor of job satisfaction than interactional justice. Moreover, the significant positive relationship between job satisfaction and organizational justice was found by Zainalipour, Fini, and Mirkamali (2010). Distributive justice and interactional justice positively correlated with four facets of job satisfaction namely, supervision, co-worker, pay and promotion and they did not have correlation with nature of job as a facet of job satisfaction. Thus, based on these previous studies, we propose that:

Proposition 1: Distributive justice is positively related with job satisfaction.

Proposition 2: Procedural justice is positively related with employee's job satisfaction.

Proposition 3: Interactional justice is positively related with employee's job satisfaction.

\subsection{Relationships between Organization Justice and Organizational Citizenship Behavior}

The organizational citizenship behavior has not strongly impact on individual performance, but also on organizations productivity and effectiveness (Turnipseed \& Rassuli, 2005). Organ and Ryan (1995) found that organizational citizenship behavior is largely encouraged by perceived organizational justice. Moon, Mayer, Kamdar, and Takeuci (2008) stated that when individual is given fair rewards compared with what they have contributed, it is a sign that abilities are valued by the organization. Several researchers have argued that distributive justice has a positive impact on OCB (Yaghoubi, Afshar, \& Javadi, 2012; Hemdi, Razali, Rashid, \& Nordin, 2012). With the same perspective, Lambert and Hogan (2013) find out that relationship between procedural justice and OCB is more intensive. In addition, Zeinabadi and Salehi (2011) in their study concluded that when academic staff sees certain procedures are fair, although they are not directly affected, they will respect as members of the organization. Furthermore, Awang and Ahmad (2015) concluded that interactional justice has significant influence on OCB. The results consistency with DiPaola and Hoy (2004), the informal praise may be the best commendation for them to exhibit OCB. So, based on literature review, we hypothesize:

Proposition 4: Distributive justice is positively related with OCB.

Proposition 5: Procedural justice is positively related with OCB.

Proposition 6: Interactional justice is positively related with OCB.

\subsection{Relationships between Employee's Job Satisfaction and $\mathrm{OCB}$}

George and Jones (2012) conducted an empirical investigation of the satisfaction and OCB relationship and found that satisfied employees have higher OCB because they want to reciprocate to the organization whose already treat them well. This results generally consistently with previous research (Wagner \& Hollenbeck, 2010). This notion has been strengthen by many studies (Foote \& Tang (2008); Intaraprasong (2012); Talachi, Gorji, \& Boerhannoeddin, 2014). Recently, Prasetio, Yuniarsih, and Ahman (2017) have found that job satisfaction has positive and significant effect on OCB with the correlation of .334. So we propose that:

Proposition 7: Employee's job satisfaction is positively related with OCB.

\section{Research Methodology}

Generally, there are many conceptual research frameworks available on organizational justice, employee's job satisfaction, and OCB.

\subsection{Measurement Issues}

To measure the various constructs, validated items were adapted from prior studies and revalidated for investigate the conceptual framework. All the focal constructs of the model were measured using reflective constructs that were adapted from literature and designed by using a seven-point Likert scale to facilitate measurement, with a rating scale from (1) "strongly disagree" to (7) "strongly agree." 
The following briefly describes the five variables should be used in the models. First, the measurement for distributive justice is drawn from a prior study, which measured the employee's perceived of equality, equity, and needs (be treated like all other people, like some other people, and like no other person). Six survey items were used to measure employees perceived on distributive justice are adapted from the studies of Leventhal (1976) and Cropanzano, Bowen and Gilliland (2007). Second, the procedural justice is defined as appropriateness of the allocation process such as consistency, lack of bias, accuracy, representation of all concerned, correction, and ethics of organization procedures, the seven items measurement for this construct is adapted from adapted from Thibaut and Walker (1975), and Leventhal (1980) studies. The third variable uses the six items measurement adapted from Bies and Moag (1986), Shapiro and Bies (1994) studies, which investigated appropriateness of the treatment employee receives from authority person for interactional justice. The fourth variable uses the five items measurement adapted from Smith, Kendall and Hulin (1969) study, which reflects employee's job satiation (Brief, 1998). Finally, the OCB is generated from the ten items measurement for this construct was adapted from prior studies of Smith, Organ and Near (1983), Podsakoff, MacKenzie, Moorman and Fetter (1990), and Williams and Anderson (1991).

\subsection{Unit of Analysis}

The prospective respondents were chosen randomly from HEls (public and private). Individuals has been employed at least one year and above will be the unit of analysis. The restriction on duration of employment is necessary for participant understand clarify about $\mathrm{HEl}$, which him or her has worked in which the experimental test of the proposed model will be conducted.

\subsection{Statistical Data Analysis}

To achieve the objectives of the study, the structural equation modeling (SEM), particular, a partial least square method (PLS) is suitable since this techniques permits the simultaneous estimation of multiple equations and performs factor analysis including regression analysis all in one step (Hair, Black, Babin, Anderson, \& Tatham, 2014). The research should follow a two steps approach. First, the measurement model is estimated based on the confirmatory factor analysis. Second, the researchers analyze the structural model and estimate the path coefficients, both for the direct as well as for the mediated effects.

\section{Conclusion}

Organizational citizenship behavior is one of the most important factor influence the organizational performance. Furthermore, the performance of HEls does not affect only the national human resources, but also impact on national economy. In this context, a conceptual framework is proposed to study the determinants of organizational citizenship behavior in the form of organizational justice and job satisfaction. Additionally, the ultimate benefits of OCB through perceived organizational justice with job satisfaction as mediator is enlightened.

\section{References}

Awang, R., \& Ahmad, W. M. R. W. (2015). The Impact of Organizational Justice on Organizational Citizenship Behavior in Malaysian Higher Education. Mediterranean Journal of Social Sciences, 6(5), 674678.

Batman, T. S., \& Organ, D. W. (1983). Job satisfaction and good solider: The relationship between affect and employee citizenship. Academy of Management Journal, 26, 587-595.

Becker, B. E., \& Gerhart, B. (1996). The Impact of Human Resource Management on Organizational Performance. The Academy of Management Journal, 39(4), 779-801.

Brief, A. P. (1998). Attitudes in and around organizations. Thousand Oaks, CA: Sage Publications.

Bies, R. J., \& Moag, J. S. (1986). Interactional justice: Communication criteria for justice. In B. Sheppard (Ed.), Research on negotiation in organizations, 1, 43-55

Chelagat, L. J., Chepkwony, P. K., \& Kemboi, A. (2015). Effect of Organizational Citizenship Behavior on Employee Performance in Banking Sector, Nairobi County, Kenya. International Journal of Business, Humanities and Technology, 5(4), 55-61.

Colquitt, J. A. (2001). On the dimensionality of organizational justice: A construct validation of a measure. Journal of Applied Psychology, 86(3), 386400.

Colquitt, J. A., Conlon, D. E., Wesson, M. J., Porter, C. O. L. H., \& Ng, K. Y. (2001). Justice at the millennium: A meta-analytic review of 25 years of organizational justice research. Journal of Applied Psychology, 86, 425-445.

Cropanzano, R., Rupp D. E., Mohler, C. J., \& Schminke, M. (2001). Three roads to organizational justice. In J. 
Ferris (Ed.), Research in Personnel and Human Resources Management, 20, 1-113.

Cropanzano R., Bowen, D. E., \& Gilliland, S. W. (2007). The management of organizational justice. Academy of Management Perspectives, 21, 34-48.

DiPaola, M., \& Hoy, W. K. (2004). Organizational citizenship of faculty and achievement of high school students. The High School Journal, 88, 16-45.

Ellickson, M. C., \& Logsdon, K. (2002). Determinants of job satisfaction of municipal government employees. Public Personnel Management, 31(3), 343-358.

Foote, D. A., \& Tang, T. L. (2008). Job satisfaction and Organizational Citizenship Behavior (OCB) Does Team Commitment Make a Difference in Selfdirected Teams? Management Decision, 46(6), 933947.

George, J. M., \& Jones, G. R. (2012). Understanding and Managing Organizational Behavior. Upper Saddle River, NJ: Prentice Hall.

Greenberg, J., \& Colquitt, J. A. (2006). Handbook of Organizational Justice. Mahwah, NJ: Lawrence Erlbaum Associates.

Intaraprasong, B., Dityen, W., Krugkrunjit, P., \& Subhadrabandhu T. (2012). Job Satisfaction and Organizational Citizenship Behavior of Personnel at One University Hospital in Thailand. Journal Medical Association Thai, 95, S102-S108.

Iqbal, K. (2013). Determinants of Organizational Justice and its impact on Job Satisfaction. A Pakistan Base Survey. International Review of Management and Business Research, 2, 49-51.

Hair, J. F., Black, W. C., Babin, B. J., Anderson, R. E., \& Tatham, R. L. (2014). Multivariate Data Analysis (4th ed.). Upper Saddle River, NJ: Prentice Hall.

Hemdi, M. A., Razali, M. A., Rashid, N. N. A., \& Nordin, R. (2012). Organizational citizenship behavior of hotel employees: Investigating the impact of organizational justice. Current Issues in Hospitality and Tourism Research and Innovations - Proceedings of the International Hospitality and Tourism Conference, IHTC 2012 (pp.159-164). International Hospitality and Tourism Conference, IHTC 2012, Kuala Lumpur, Malaysia, September 3-5, 2012.

Koster, F., \& Sanders, K. (2006). Organizational citizens or reciprocal relationships? An empirical comparison. Personnel Review, 35(5), 519-537.

Lambert, E. G., \& Hogan, N. L. (2013). The Association of Distributive and Procedural Justice with Organizational Citizenship Behavior. Prison Journal, 93, 313-334.

Lee, M. N. (2004). Global Trends, National Policies and Institutional Responses: Restructuring Higher
Education in Malaysia. Educational Research for Policy and Practice, 3(1), 31-46.

Leventhal, G. S. (1976) Fairness in social relationships. In J. W. Thibaut, J. T. Spence \& R. C. Carson (eds.), Contemporary Topics in Social Psychology (pp. 211239). Morristown, NJ: General Learning Press.

Leventhal, G. S. (1980). What should be done with equity theory? In Social Exchange: Advances in Theory and Research, 27-55.

MacKenzie, S. B., Podsakoff, P. M., \& Fetter, R. (1991). Organizational citizenship behavior and objective productivity as determinants of managerial evaluations of salespersons' performance. Organizational Behavior and Human Decision Processes, 50, 123-150.

Masterson, S. S., Lewis, K., Goldman, B. M., \& Taylor, M. S. (2000). Integrating Justice and Social Exchange: The Differing Effects of Fair Procedures and Treatment on Work Relationships. The Academy of Management Journal, 43(4), 738-748.

Moon, H., Mayer, D. M., Kamdar, D., \& Takeuci, R. (2008). Me or we? The role of personality and justice as other-centered antecedents to innovative citizenship behaviors with in organizations. Journal of Applied Psychological Association, 93, 84-94.

Organ, D. W., \& Ryan, K. (1995). A Meta-Analytic Review of Attitudinal and Dispositional Predictors of Organizational Citizenship Behavior. Personnel Psychology, 48, 775-802.

Organ, D. W. (1998). Organizational citizenship behavior: The good soldier syndrome. Canada: Lexington Books.

Podsakoff, P. M., MacKenzie, S. B., Moorman, R. H., \& Fetter, R. (1990). Transformational leader behaviors and their effects on followers' trust in leader, satisfaction, and organizational citizenship behaviors. Leadership Quarterly, 1(2), 107-142.

Podsakoff, P. M., \& Mackenzie, S. B. (1994). Organizational citizenship behavior and sales unit effectiveness. Journal of Marketing Research, 31, 351-363.

Podsakoff, P. M., Mackenzie, S. B., Paine, J. B., \& Bachrach, D .G. (2000). Organizational citizenship behaviors: A critical review of the theoretical and empirical literature and suggestions for future research. Journal of Management, 26(3), 513-563.

Prasetio, A. P., Yuniarsih, T., \& Ahman, E. (2017). Job Satisfaction, Organizational Commitment, and Organizational Citizenship Behavior in State-owned Banking. Universal Journal of Management, 5(1), 3238.

Shapiro, D. L., \& Bies, R. J. (1994). Threats, bluffs, and disclaimers in negotiations. Organizational Behavior 
and Human Decision Process, 60, 14-35.

Smith, P. C., Kendall, L. M., \& Hulin, C. C. (1969). The measurement of satisfaction in work and retirement. Chicago, IL: Rand McNally.

Smith, C. A., Organ D. W., \& Near, J. P. (1983). Organizational citizenship behavior: Its nature and antecedents. Journal of Applied Psychology, 68, 653663.

Spector, P. E. (1997). Job Satisfaction: Application, assessment, causes, and consequences. Thousand Oaks, CA: Sage Publications, Inc.

Talachi, R. K., Gorji, M. B., \& Boerhannoeddin, A. B. (2014). The Role of Job Satisfaction in Employees' OCB. Collegium Antropologicum, 38(2), 429-436.

Thibaut, J., \& Walker, L. (1975). Procedural Justice: A Psychological analysis. Hillsdale, NJ: Lawrence Erlbaum Associates.

Turnipseed, D. L., \& Rassuli, A. (2005). Performance perceptions of organizational citizenship behaviours at work: A bi-level study among managers and employees. British Journal of Management, 16(3), 231-244.

Wagner, J. A., \& Hollenbeck, J. R. (2010). Organization Behavior, Securing Competitive Advantage (revised edition). New York: Routledge.
Williams, L. J., \& Anderson, S. E. (1991). Job satisfaction and organizational commitment as predictors of organizational citizenship and in-role behaviors. Journal of Management, 17, 601-617.

Yadav, R. (2016). Antecedents and Consequences of Organizational Justice. Management Insight, 12(2), $66-77$.

Yaghoubi, M., Afshar, M., \& Javadi, M. (2012). A study of relationship between the organizational justice and organizational citizenship behavior among nurses in selected hospitals of Isfahan University of Medical Sciences. Iranian Journal of Nursing and Midwifery Research, 17, 456-460.

Zainalipour, H., Fini, A. A. S., \& Mirkamali, S. M. (2010). A Study of Relationship between Organizational Justice and Job Satisfaction among Teachers in Bandar Abbas Middle School. Procedia - Social and Behavioral Sciences, 5(1), 1986-1990.

Zeinabadia, H., \& Salehi, K. (2001). Role of procedural justice, trust, job satisfaction, and organizational commitment in Organizational Citizenship Behavior (OCB) of teachers: Proposing a modified social exchange model. Procedia - Social and Behavioral Sciences, 29, 1472 - 1481. 


\section{APPENDIX}

Proposed Measurement Items for Questionnaire

\begin{tabular}{|c|c|c|}
\hline Measure item & Indicators & $\begin{array}{l}\text { Sources on which item } \\
\text { is based }\end{array}$ \\
\hline \multirow[t]{2}{*}{ Distributive justice } & $\begin{array}{l}\text { 1. Does your (outcome) reflect the effort you have put into your work? } \\
\text { 2. Is your (outcome) appropriate for the work you have completed? } \\
\text { 3. Does your (outcome) reflect what you have contributed to the organization? } \\
\text { 4. Is your (outcome) justified, given your performance? }\end{array}$ & Leventhal (1976) \\
\hline & $\begin{array}{l}\text { 5. Is your (outcome) provided based on your personal requirements? } \\
6 . \quad \text { Is the compensation provided each employee roughly the same? }\end{array}$ & Cropanzano (2007) \\
\hline \multirow[b]{2}{*}{ Procedural justice } & $\begin{array}{l}\text { 1. Have you been able to express your views and feelings during those } \\
\text { 2. Have you had influence over the (outcome) arrived at by those procedures? }\end{array}$ & $\begin{array}{l}\text { Thibaut and Walker } \\
\text { (1975) }\end{array}$ \\
\hline & $\begin{array}{l}\text { 3. Have those procedures been applied consistently? } \\
\text { 4. Have those procedures been free of bias? } \\
\text { 5. Have those procedures been based on accurate information? } \\
\text { 6. Have you been able to appeal the (outcome) arrived at by those procedures? } \\
\text { 7. Have those procedures upheld ethical and moral standards? }\end{array}$ & Leventhal (1980) \\
\hline \multirow[b]{2}{*}{ Interactional justice } & $\begin{array}{l}\text { 1. Has (he/she) refrained from improper remarks or comments? } \\
\text { 2. Has (he/she) been candid in (his/her) communications with you? } \\
\text { 3. Has (he/she) explained the procedures thoroughly? }\end{array}$ & Bies and Moag (1986) \\
\hline & $\begin{array}{l}\text { 4. Were (his/her) explanations regarding the procedures reasonable? } \\
\text { 5. Has (he/she) communicated details in a timely manner? } \\
\text { 6. Has (he/she) seemed to tailor (his/her) communications to individuals' specific } \\
\text { needs? }\end{array}$ & Shapiro and Bies (1994) \\
\hline Job satisfaction & $\begin{array}{l}\text { 1. Satisfy with him/her work-itself } \\
\text { 2. Satisfy with him/her compensation and benefits } \\
\text { 3. Satisfy with him/her promotion or recognition } \\
\text { 4. Satisfy with him/her co-worker relationships } \\
\text { 5. Satisfy with him/her supervision }\end{array}$ & $\begin{array}{l}\text { Smith, Kendall and Hulin } \\
\text { (1969) }\end{array}$ \\
\hline $\begin{array}{l}\text { Organizational } \\
\text { citizenship behavior }\end{array}$ & $\begin{array}{l}\text { 1. } \text { Adequately completes assigned duties. } \\
\text { 2. Fulfills responsibilities specified in job description } \\
\text { 3. } \\
\text { 4. } \text { Merforms tasks that are expected of him/he } \\
\text { 5. Goes out of way to help new employee } \\
\text { 6. Helps others who have heavy work loads } \\
\text { 7. Helps others who have been absent } \\
\text { 8. } \\
\text { 9. } \text { Voking suggestions to improve the organization. } \\
\text { 10. } \text { Attending functions that are not required, but that help the HEl's image. }\end{array}$ & $\begin{array}{l}\text { Smith, Organ and Near } \\
(1983) \\
\text { Williams and Anderson } \\
\text { (1991) } \\
\text { Podsakoff, MacKenzie, } \\
\text { Moorman and Fetter } \\
\text { (1990) }\end{array}$ \\
\hline
\end{tabular}

